Kumawula, Vol. 1, No.3, Desember 2018, Hal 150 - 169 DOI:http://10.24198/kumawula.v1i3.20932

ISSN 2620-844X (online)

Tersedia online di http://jurnal.unpad.ac.id/kumawula/index

\title{
KAMPUNG IT - MENUJU PEMBANGUNAN BERKELANJUTAN
}

\author{
Rudolf Wirawan \\ Flinders Adjunct Senior Researcher \& Flinders Industry Partner \\ College of Business, Government and Law Resilience Institute, Flinders University. SA, Australia \\ Address: GPO Box 2100 Adelaide SA 5001 Australia \\ rudolf.wirawan@flinders.edu.au Phone:+61402236310
}

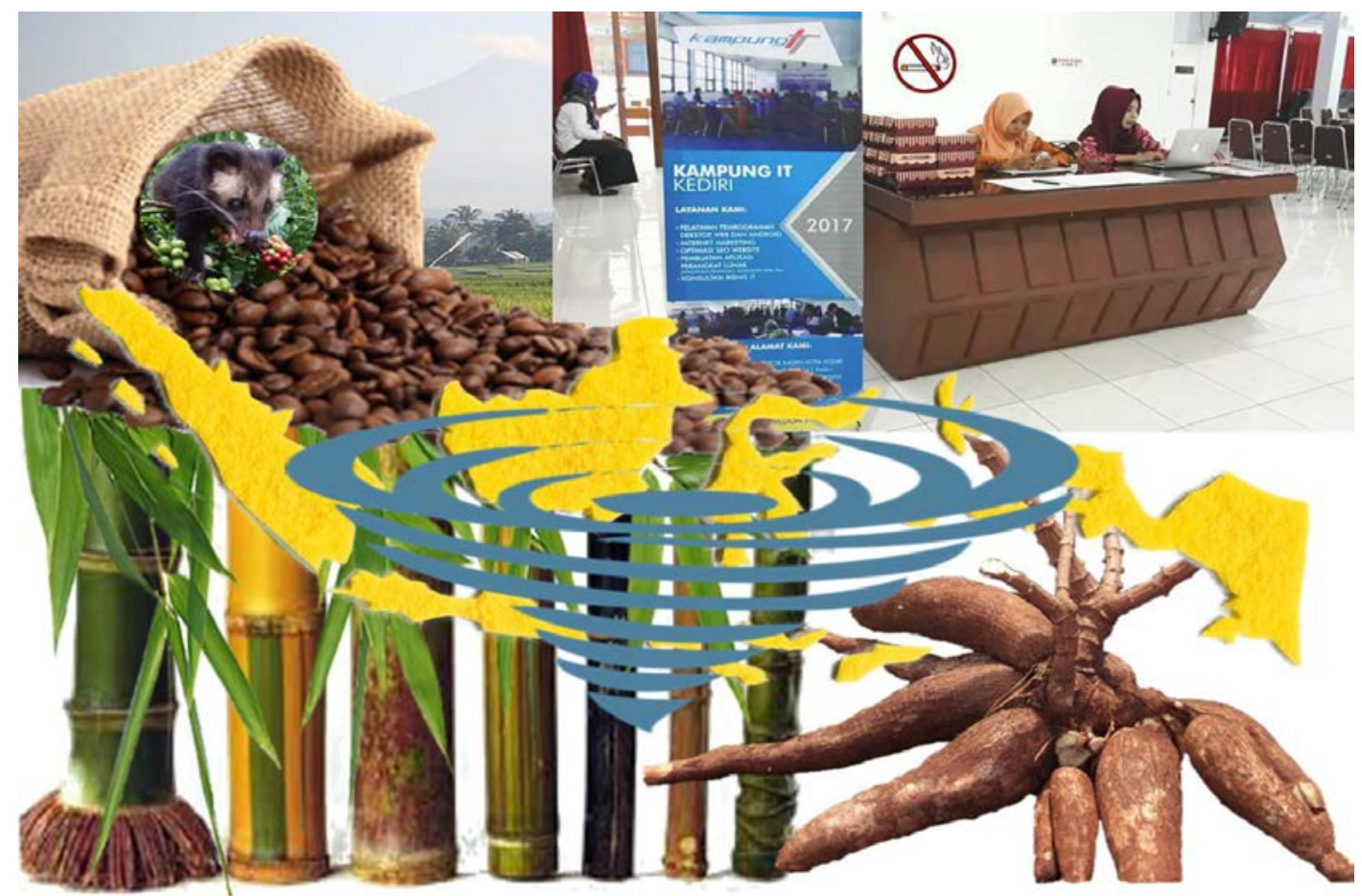

\begin{abstract}
ABSTRAK
Kegiatan pertanian tradisional di Indonesia dapat memainkan peran penting dalam pembangunan berkelanjutan. Tantangan utama yang dihadapi adalah kecenderungan konsentrasi perkotaan, yang mengurangi potensi ini karena pengurangan dukungan pertanian sebagai individu pindah ke kota-kota Besar. Makalah ini mengeksplorasi konsep 'Kampung IT, yang melibatkan pengembangan pertanian dan kegiatan pengembangan TI secara bersama-sama untuk memungkinkan hasil yang mencapai pertumbuhan ekonomi melalui praktik berkelanjutan sambil membantu mengatasi perubahan iklim.
\end{abstract}

Kata kunci: Pembangunan berkelanjutan, perubahan iklim, desa pintar

\section{SMARTVILLAGE - TOWARDS SUSTAINABLE DEVELOPMENT}

\begin{abstract}
Traditional agricultural activities in Indonesia can play a significant part in sustainable development. A key challenge faced is the trend towards urban concentration, which reduces this potential due to
\end{abstract}


the reduction in agricultural support as individuals relocate to the main cities. This paper explores the concept of 'Smartvillages', which involves bringing farming development and IT development activities together to enable outcomes that achieve economic growth through sustainable practices whilst helping to address climate change.

Keywords: Sustainable development, climate change, Smartvillage

\section{PENDAHULUAN}

Daerah pedesaan di Indonesia berlimpah sumber daya alam, yang dapat membantu mendukung mata pencaharian yang berkelanjutan; Namun, prospek pekerjaan telah menyebabkan banyak individu pindah dari daerah pedesaan untuk mengejar pekerjaan industri dan pabrik di kota-kota.

Kota-kota di Indonesia tumbuh, lebih cepat daripada negara Asia lainnya, dengan laju 4,1\% per tahun. Peningkatan urbanisasi diharapkan dapat mendorong pertumbuhan ekonomi, tetapi ini terhambat oleh kurangnya investasi dalam infrastruktur, yang telah menyebabkan kemacetan, polusi dan risiko bencana.

Untuk menciptakan mata pencaharian yang berkelanjutan, individu harus dapat memperoleh hasil yang lebih baik dari produk mereka melalui akses pasar pelanggan yang lebih baik dan pengurangan biaya rantai pasokan.

Makalah ini membahas pengembangan 'Kampung IT' di seluruh Indonesia, yang merupakan komunitas dengan beragam pengembangan TI dan keterampilan bertani yang berbaur untuk memungkinkan produktivitas secara berkelanjutan.

Sebaliknya, petani memiliki lebih banyak kesulitan dalam melayani pelanggan global (dan beberapa lokal) karena tantangan logistik dan biaya dalam kaitannya dengan transportasi dan pemenuhan barang fisik.

Pengembangan Smartvillages diharapkan dapat memperbaiki situasi dari waktu ke waktu melalui hal- hal berikut:

- Pengembang TI di area tersebut meningkatkan pembelian dan konsumsi hasil panen petani.

- Meningkatkan kegiatan ekonomi dan fokus di bidang tersebut dapat meningkatkan infrastruktur dan logistik yang mengarah ke akses yang lebih baik ke pasar global bagi para petani.

- Perpaduan fasilitas modern dan tradisional dapat menciptakan peluang pariwisata.

Secara keseluruhan, kegiatan ini akan membantu meningkatkan kemampuan Indonesia 
dengan negara-negara maju, tetapi juga secara signifikan membantu upaya mitigasi perubahan iklim.

Makalah ini mengacu pada contoh-contoh spesifik bahwa penulis telah terlibat dalam lebih dari 14 tahun terakhir bekerja dengan pemerintah Indonesia dan Australia pada kegiatan yang membantu menggerakkan ekonomi hijau dan merespon secara efektif terhadap perubahan iklim.

\section{METODE}

Metode yang digunakan adalah metode yang sangat murah, mudah dan cepat, yaitu melalui Teknologi Informasi dan Komunikasi yang semakin marak dan mudah di jangkau. Apalagi Indonesia adalah negara kepulauan, sehingga hanya melalui satelit, seluruh pelosok di Indonesia dari Sabang sampai Merauke akan sangat mudah di jangkau. Metode ini mengeksplorasi konsep ‘Kampung IT, yang melibatkan pengembangan pertanian dan kegiatan pengembangan TI secara bersama-sama untuk memungkinkan hasil yang mencapai pertumbuhan ekonomi melalui praktik berkelanjutan sambil membantu mengatasi perubahan iklim.

\section{"Kampung IT" Pilot}

Pada tahun 2003, setelah penulis mendirikan perusahaannya pada tahun 2002, Wirasoft Consulting, ia membangun sebuah "pilot" Kampung IT di Semarang, Jawa Tengah Indonesia seperti yang digambarkan pada Gambar 1.

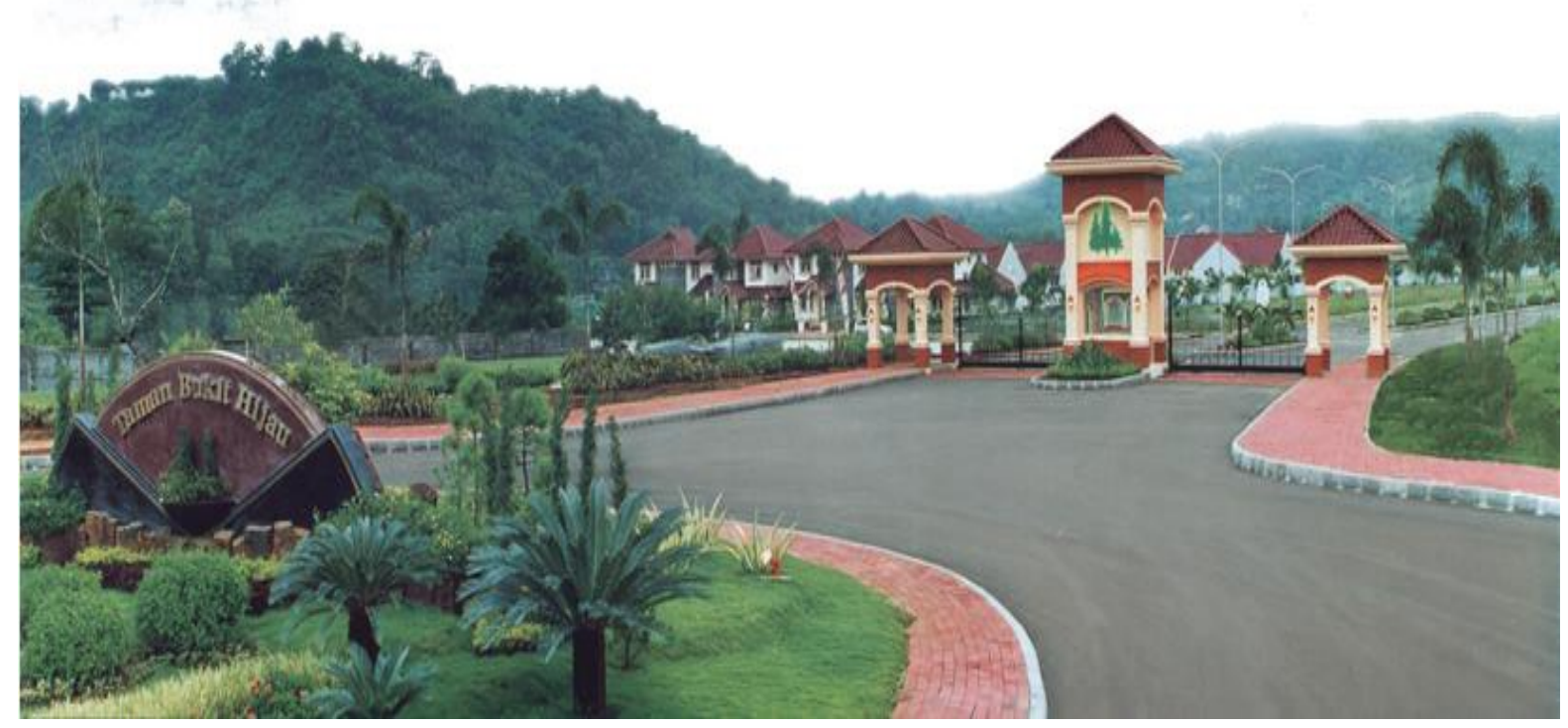

Figure 1 Smartvillage in Semarang, Central Java, Indonesia

Karena pendanaan dan dukungan terbatas, pilot ini tidak diluncurkan sampai tahun 
2012 setelah mendapat dukungan dari Jaringan Diaspora Indonesia (IDN) yang dipimpin oleh Dr. Dino Patti Djalal, mantan Duta Besar Indonesia untuk Amerika Serikat. IDN berfokus pada pemberdayaan masyarakat Indonesia melalui dukungan yang lebih baik.

\section{Kampung IT Pertama}

Kampung IT pertama berhasil didirikan pada achir tahun 2017 di Kediri, Jawa Timur dengan dukungan individu dan organisasi sebagai berikut:

- Walikota Kediri (Bpk. Abdullah Abu Bakar)

- KADIN Kediri

- Universitas PGRI

- Politeknik Kediri

- $\quad$ Bank Indonesia (BI) cabang Kediri, Bank Jatim Cabang Kediri

- Pebisnis Kediri.

Acara ini telah dipromosikan dan diorganisir oleh sebuah organisasi sosial yang disebut SANYURI Indonesia (Santri Pagujuban Kediri).

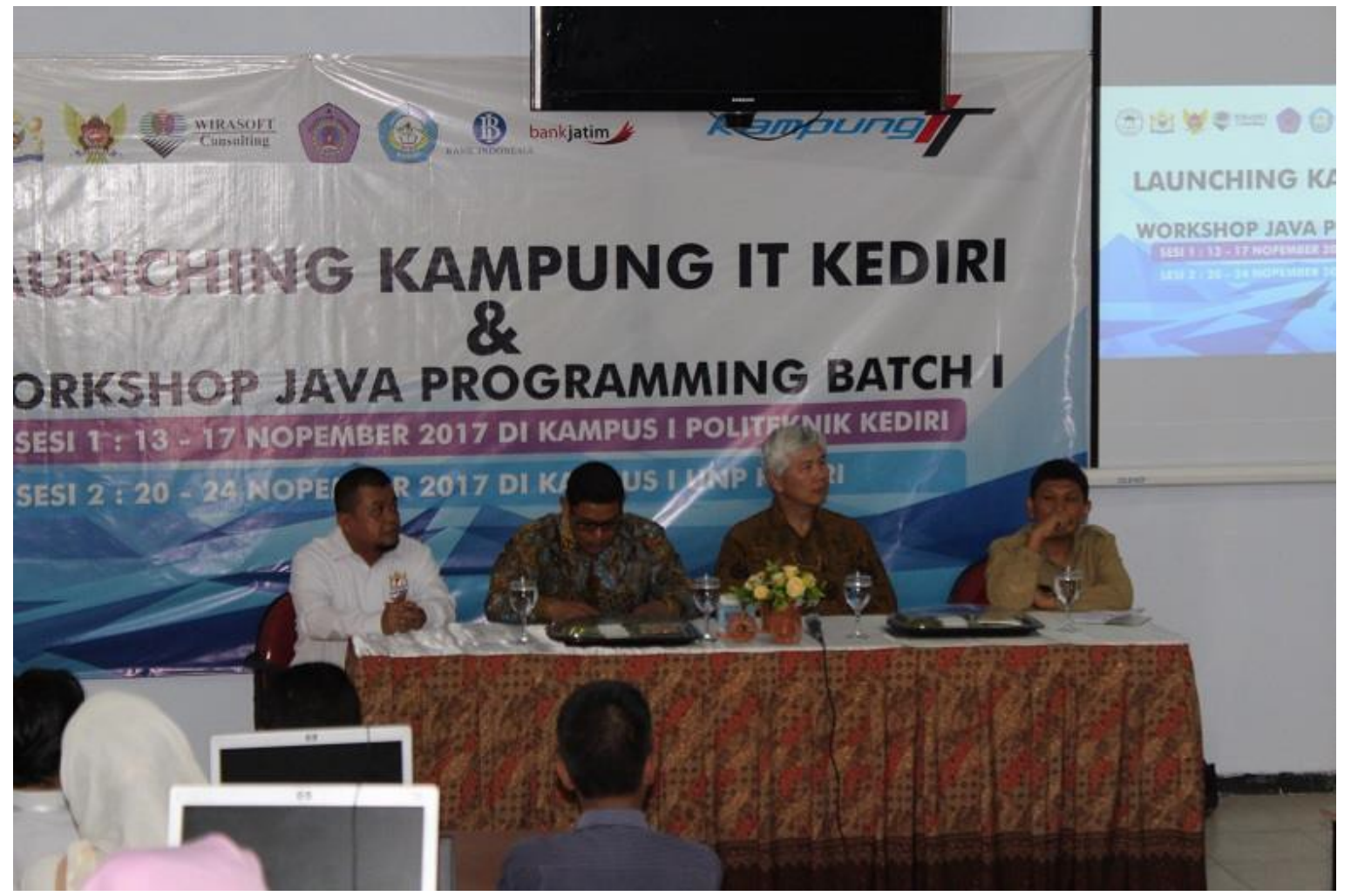

Figure 2 The Launching of Kampung IT (Smartvillage) in Kediri, East Java

Gambar 2 di atas menunjukkan Walikota Kediri Abdullah Abu Bakar membuka Peluncuran Kampung IT Kota Kediri dan Pendidikan Pemrograman Java di Kampus Politeknik Kediri 1, Senin (13/11/2017). 
Program ini adalah yang pertama di Indonesia. "Saya sangat senang dan sangat mendukung program ini untuk menerapkan desa IT," kata Abdullah Abu Bakar pada kesempatan tersebut. Ia berharap program ini akan terus berlanjut dan dapat meningkatkan kompetensi para programmer terutama di Kediri.

"Semua telah menggunakan teknologi IT. Di Kota Kediri sekarang menggunakan layanan berbasis online seperti Voice of Citizens of Kediri (Surga), tentang administrasi populasi, lisensi online, UN online, dll. Harapan saya dengan program TI setidaknya layanan untuk komunitas berbasis IT dapat disederhanakan, "tambahnya.

Acara ini dihadiri oleh Ketua Kadin Kediri-HM. Sholikin, perwakilan dari BI cabang Kediri, Bank Jatim Cabang Kediri, Ketua Sanyuri Kota Kediri - Drs. Setyohadi, perwakilan dari Diskominfo- Haris Candra Purnam, Direktur Politeknik Kediri-Drs, Rektor kampus UNP, Cahaya Surya, STIMIK, UNIK, dan diikuti oleh 24 peserta termasuk dosen, mahasiswa dan alumni Poltek dan masyarakat umum.

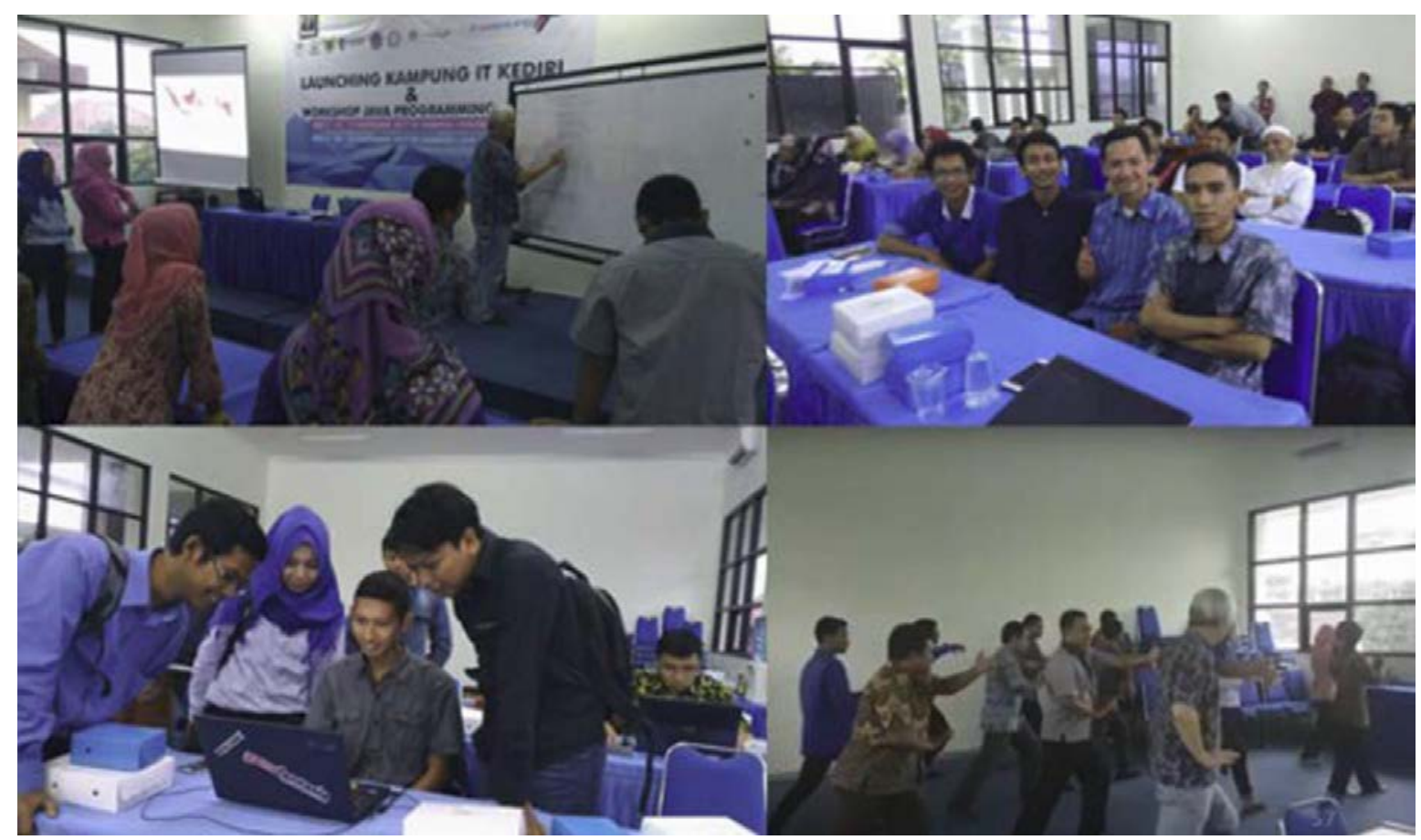

Figure 3 Kampung IT (Smartvillage) Workshop in Kediri, East Java

Dua (2) minggu lokakarya seperti yang digambarkan pada Gambar 3 di atas diadakan dalam dua (2) sesi. Yang pertama pada 13-17 November 2017 di Polytech Kediri dan yang kedua diadakan pada 20-25 November 2017 di Universitas UNP, Kediri. Selain itu, MoU antara Polytech dari Kediri dan Wirasoft ditandatangani. 


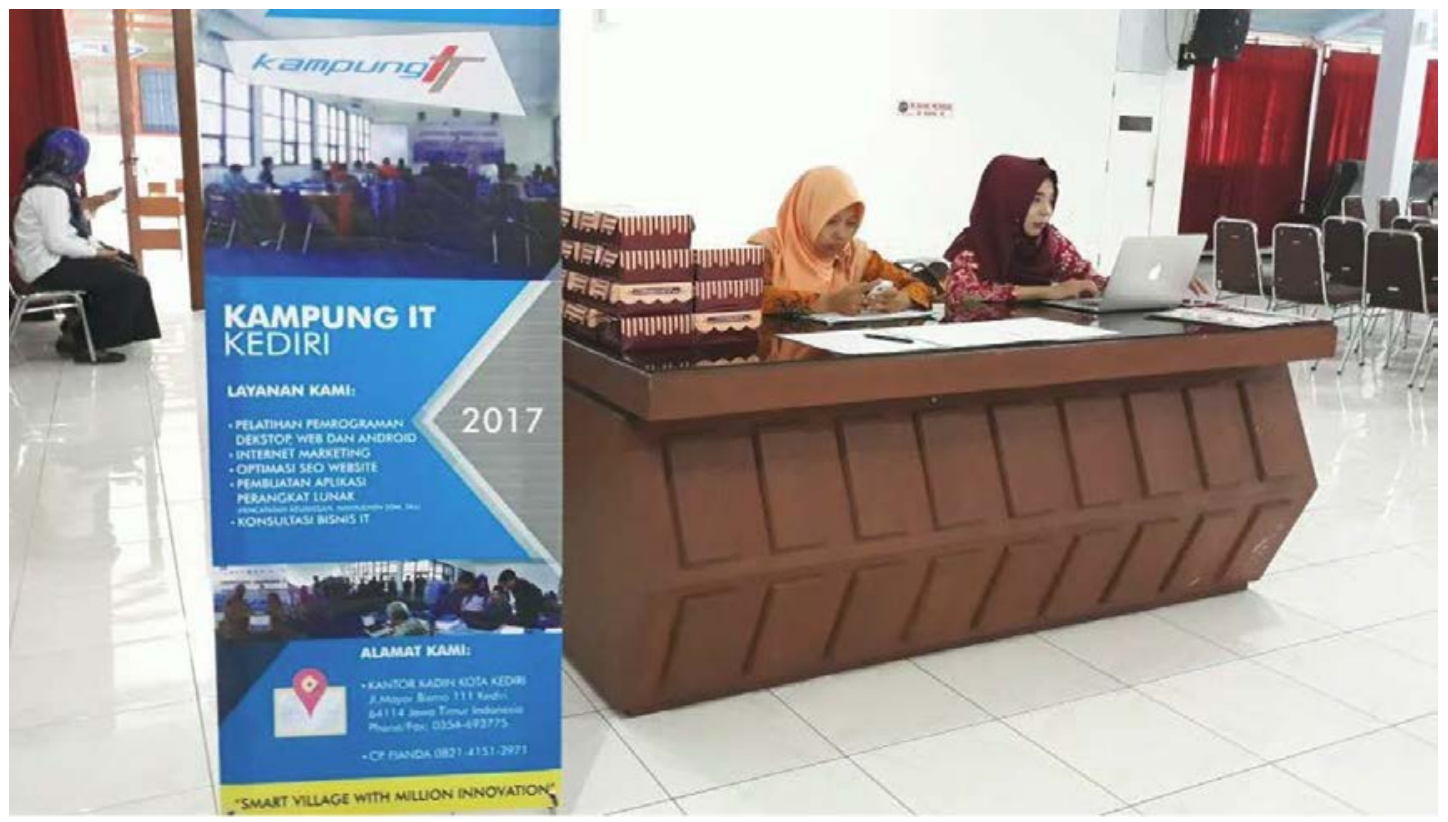

Figure 4 IT Services and Education in Kampung IT (Smartvillage) Kediri, East Java

Sebagai hasil dari lokakarya yang digambarkan pada Gambar 4, Kampung IT (Smartvillage) di Kediri saat ini siap dengan pendidikan ICT tingkat lanjutan serta layanan TI untuk masyarakat lokal, pemerintah dan bisnis.

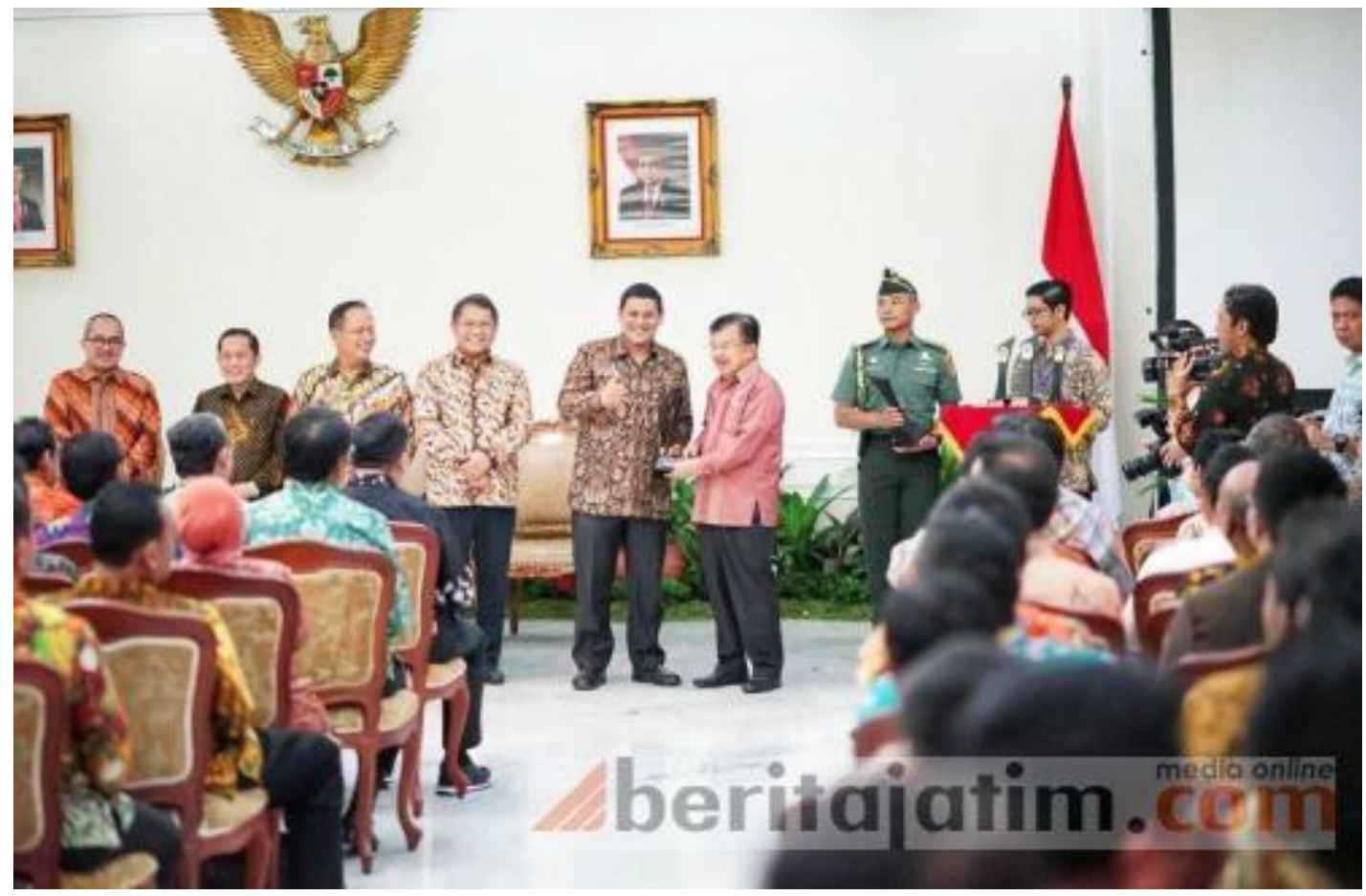

Figure 5 The Mayor of Kediri won the main award of the Smart Indonesia City Rating 2017

Seperti yang digambarkan pada Gambar 5, satu bulan setelah keberhasilan meluncurkan Kampung IT, Walikota Kediri, Bapak Abdullah Abu Bakar menerima penghargaan utama 
dari Smart Indonesia City Rating 2017 dari Wakil Presiden Indonesia, Bapak Jusuf Kalla di istana. Senin (11/12/2017).
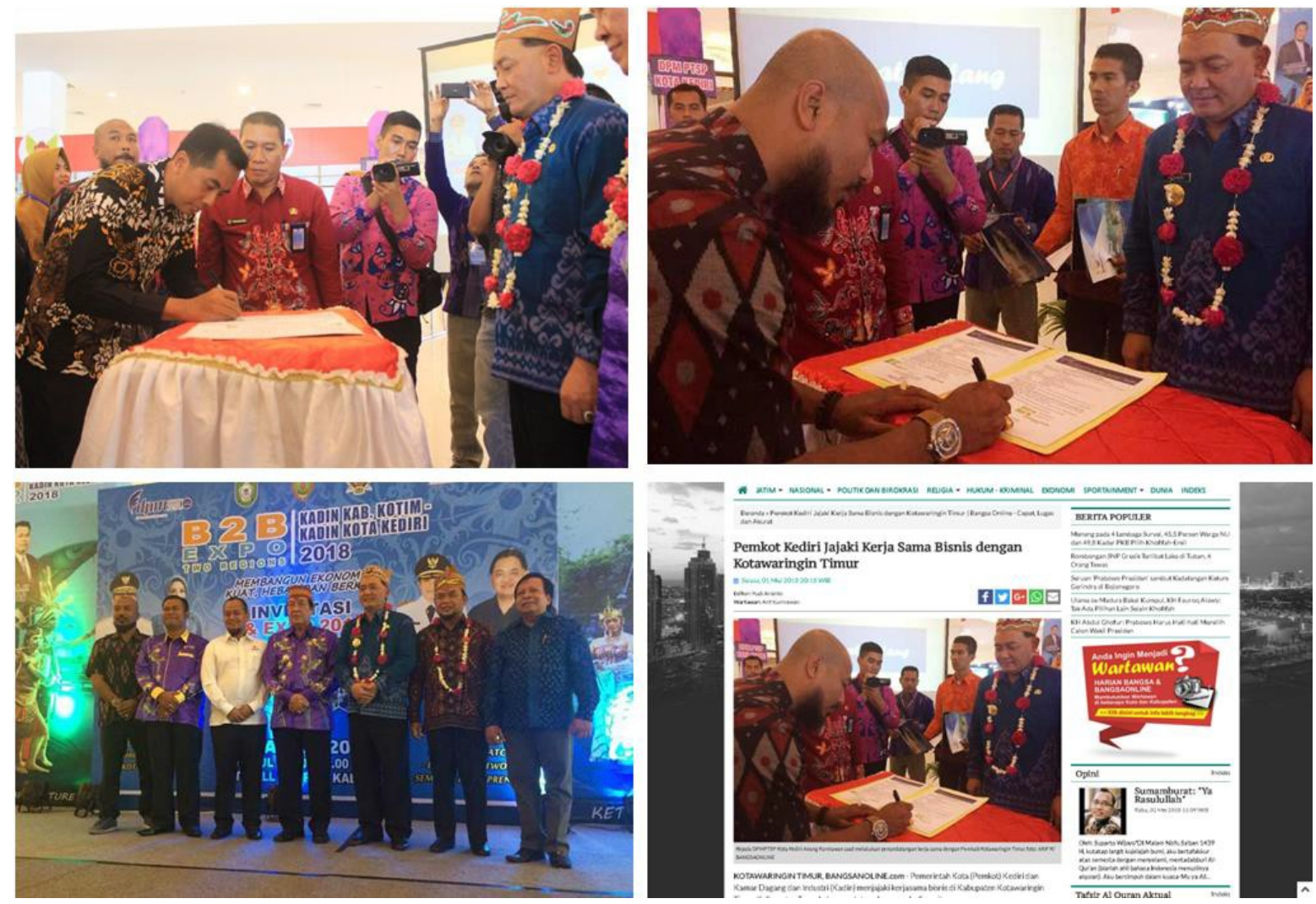

Figure 6 The signing of MoU

Gambar 6 di atas menunjukkan Pemerintah Kota Kediri dan Kamar Dagang dan Industri (KADIN) sedang menjajaki kerjasama bisnis di Sampit, Kalimantan Tengah.

Karena keberhasilan proyek Smartvillage di Kediri, Jawa Timur tahun lalu dan Smartvillage di Sampit, Kalimantan Tengah awal tahun 2018, kami akan melanjutkan upaya kami untuk mendirikan Smartvillage ketiga di Alamendah, Jawa Barat bekerja sama dengan Prof Ida Widianingsih dari universitas UNPAD, Rudolf Wirawan dari Wirasoft, Prof. Janet McIntyre dari Flinders University serta Prof Norma Romm dari University of South Africa (UNISA ${ }^{1}$ ).

\section{UNPAD International Symposium 2017}

Pada bulan Desember 2017 universitas UNPAD telah menyelengarakan Simposium Internasional tentang Mixed Methods.

\footnotetext{
${ }^{1}$ https://www.unisa.ac.za/sites/corporate/default
} 


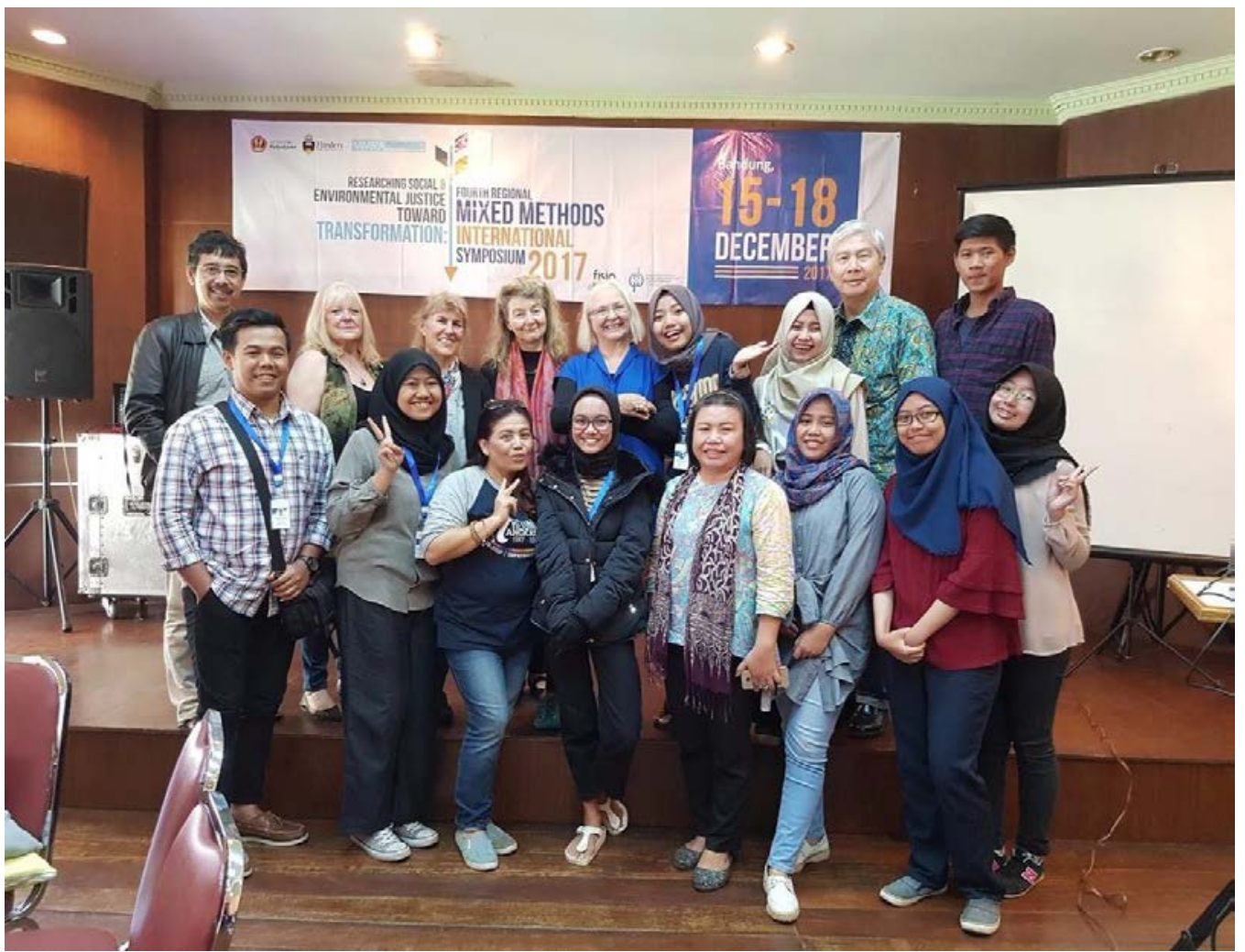

Figure 7 International Symposium at UNPAD, West Java on 15-18 December 2017

Gambar 7 di atas menunjukkan Simposium Internasional di UNPAD, Jawa Barat pada 15-18 Desember 2017.

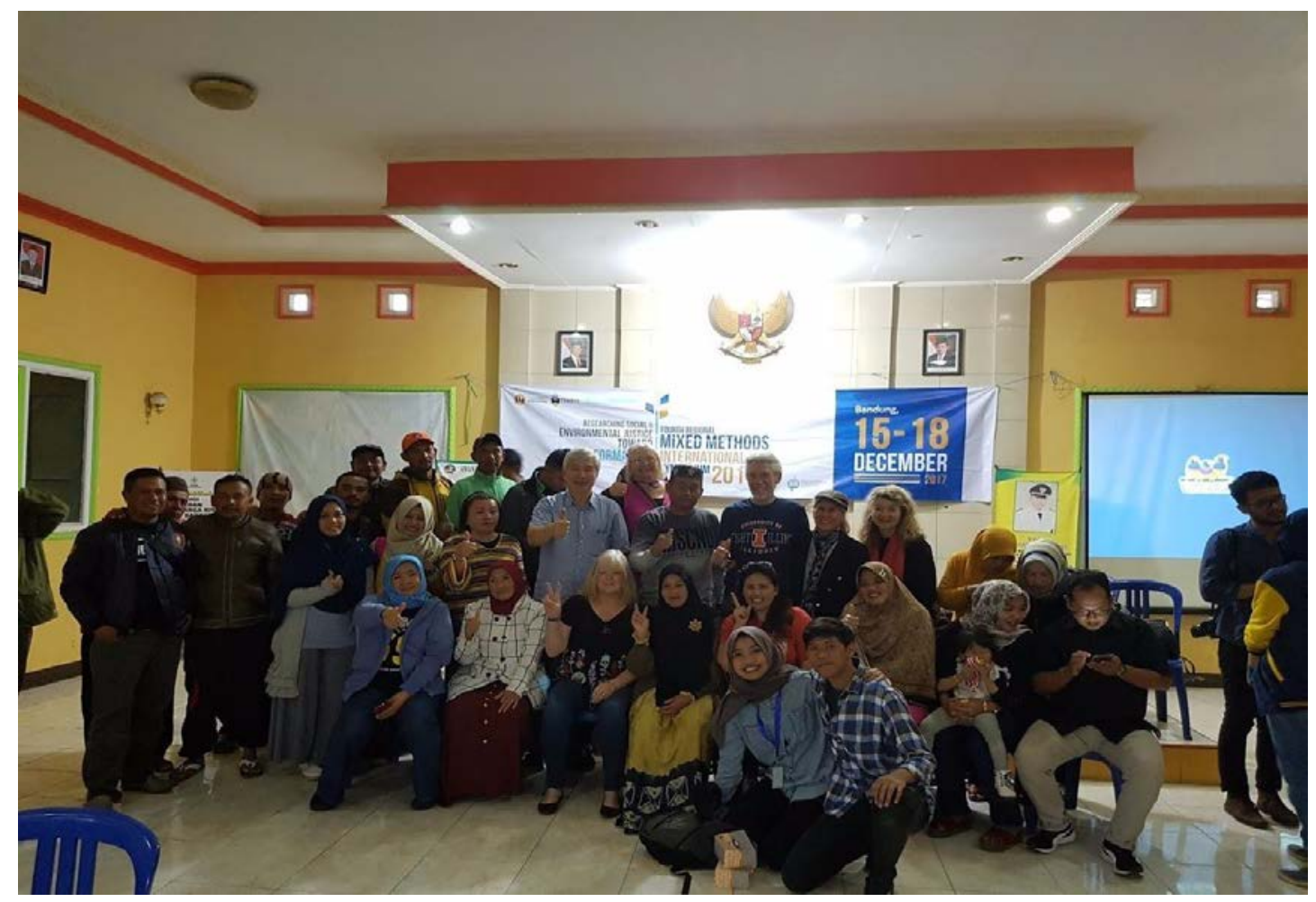




\section{Figure 8 Local villagers at Alamendah, West Java with Kampung IT}

Seperti yang ditunjukkan pada Gambar 8 di atas, setelah simposium, kami mengunjungi desa Alamendah di Jawa Barat dan berdiskusi dengan warga desa tentang pendirian Kampung IT (Smartvillage) di Alamendah bekerjasama dengan UNPAD, Wirasoft, UNISA dan Flinders dan telah terinspirasi oleh potensi untuk memberdayakan penduduk desa setempat.

Dalam seminar mengenai Kampung IT di simposium tersebut, Prof Norma Romm dan Prof Janet McIntyre merencanakan untuk mendirikan Kampung IT di Afrika Selatan melalui pengembangan kerjasama internasional untuk memulai pusat pengembangan regional.

\section{Global Kampung IT}

Gagasan untuk mendirikan Kampung IT di Afrika Selatan telah mencetuskan gagasan untuk mendirikan TI Kampung secara global dan bekerja sama antara Pemerintah Indonesia dan negara terkait yang juga terinspirasi untuk membangun Kampung IT di desa-desa mereka.

Global Kampung IT akan menjadi upaya bersama antara universitas yang dipimpin oleh Prof Janet McIntyre dari universitas Flinders, Prof Norma Romm dari UNISA (Universitas Afrika Selatan), Prof Ida Widianingsih dari UNPAD (Universitas Padjajaran di Indonesia) dan Rudolf Wirawan dari Wirasoft Pty Ltd, sebuah perusahaan Australia yang berlokasi di Sydney.

\section{Memberi Kembali Kepada Komunitas}

\section{Giving Back To The Community}

\section{Meningkatkan Profil IDN dan Inisiatif}

Sejak berdirinya organisasi Jaringan Diaspora Indonesia yang pertama pada tahun 2013 di Australia, penulis telah aktif mendukung organisasi dan menjabat sebagai Presiden Diaspora Network

Indonesia (IDN) di negara bagian New South Wales (NSW), Australia hingga 2017 dan karena banyak hasil nyata telah dicapai di Australia dan Indonesia, penulis telah terpilih secara global sebagai Wakil Presiden untuk Australia dan Oceania dari 2015 hingga 2017.

Hasilnya telah didokumentasikan dalam Diaspora Indonesia dalam Rapat Umum Tahunan Australia 2017 "Diaspora Australia Beraksi Bukan Sekedar Berjanji". 
Sebagai Presiden Diaspora di NSW, penulis telah berhasil dalam mempromosikan Australia ke Indonesia, misalnya Smart Cattle Tracking System (SCTS), yang dikembangkan oleh Wirasoft di Australia sebagai tanggapan atas seruan oleh mantan Presiden Indonesia, Dr Susilo Bambang Yudhoyono untuk Swasembada Daging Indonesia.

SCTS saat ini sedang dalam pembahasan untuk dikembangkan lebih lanjut di Kampung IT Kediri di bawah pengawas Prof Muladno, Profesor Pemuliaan Hewan dan Genetika di Institut Pertanian Bogor (IPB) untuk mengelola kebijakan strategis dalam pembangunan 54 Sekolah Peternakan Rakyat seperti yang digambarkan pada Gambar. 9 di bawah.

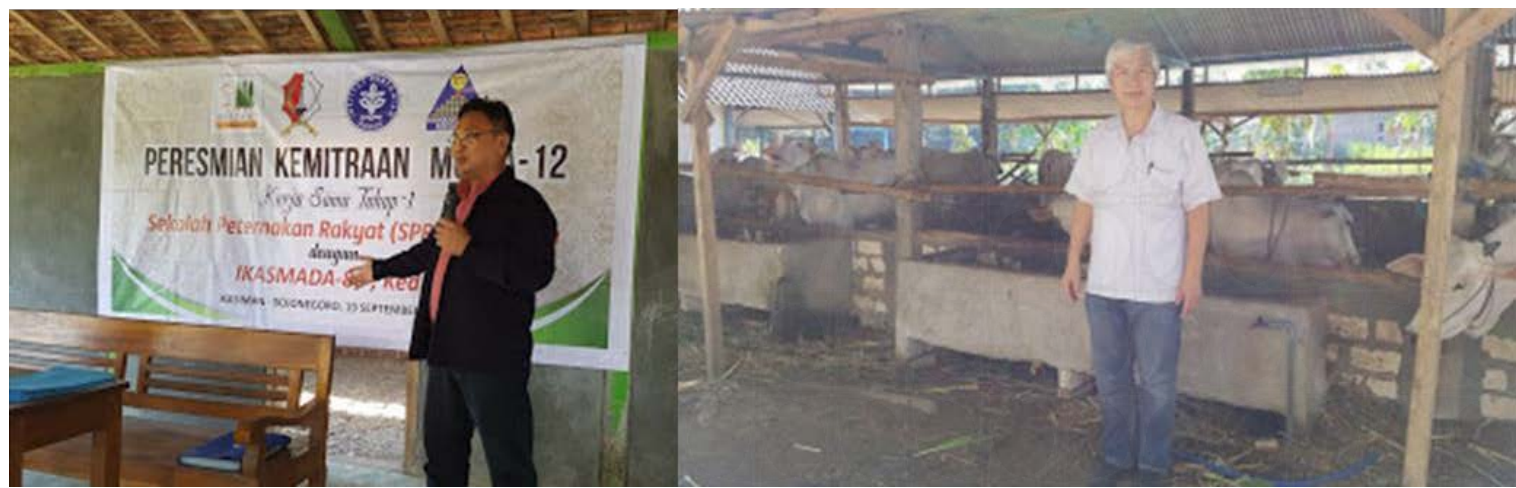

Figure 9 Prof Muladno and Rudolf at the launching of the People Ranch School in East

Java Penelitian Bersama Dengan Universitas Flinders

Kemitraan dengan Flinders University dan karya-karya Prof Janet McIntyre dari Flinders telah mengarah ke makalah penelitian bersama berikut yang diterbitkan oleh Springer Publisher:

- Jalan menuju Kesejahteraan: Tantangan Karbon Rendah untuk Hidup Secara Berwawasan dan Baik: Desain dan Pendidikan Partisipatif tentang Mitigasi, Adaptasi, Tata Kelola dan Akuntabilitas

- Menyeimbangkan Individualisme dan Kolektivisme: Keadilan Sosial dan Lingkungan

Makalah di atas fokus pada strategi khusus untuk meningkatkan hasil sosial dan lingkungan. Strategi dan prinsip yang disoroti dalam makalah-makalah ini sedang diterapkan ke Desa Cerdas di Indonesia dan juga akan diterapkan dalam pembentukan Desa Cerdas di negaranegara lain.

\section{Keunikan Kopi Indonesia}

Indonesia, juga dikenal sebagai Nusantara adalah istilah Indonesia kontemporer untuk kepulauan Indonesia. Ini berasal dari Jawa Kuno dan secara harfiah berarti "nusantara", adalah produsen kopi terbesar keempat di dunia sejak 2014. 


\section{Rasa Beragam Kopi Indonesia}

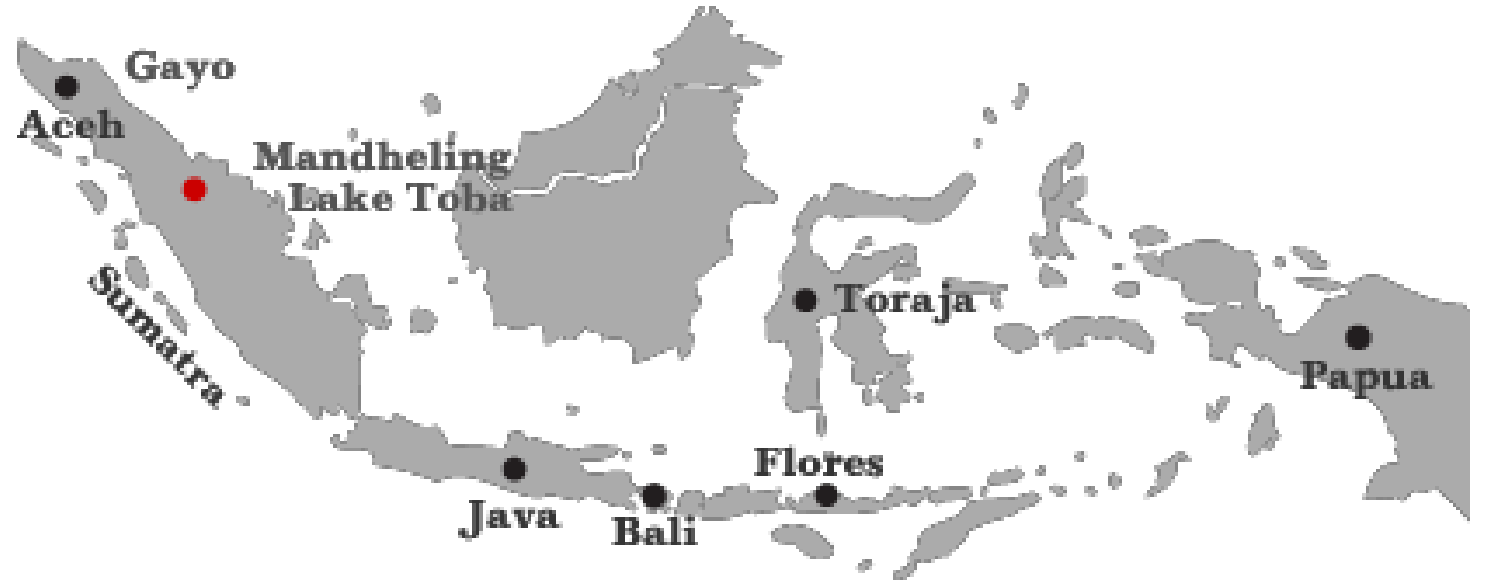

Figure 10 Indonesian Coffee Map (Source: Quintino's Coffee)

Seperti yang digambarkan dalam Fig.10, kopi di Indonesia dimulai dengan sejarah kolonialnya, ketika gubernur Belanda di Malabar (India) mengirim bibit kopi Arabika (Coffea Arabica) Yamani atau Arabika kepada gubernur Belanda Batavia (sekarang Jakarta) pada 1696, dan memainkan peranan penting dalam pertumbuhan negara.

Indonesia terletak dengan geografi yang ideal untuk perkebunan kopi, dekat khatulistiwa dan dengan banyak daerah pegunungan di seluruh pulau, menciptakan iklim mikro yang cocok untuk pertumbuhan dan produksi kopi.

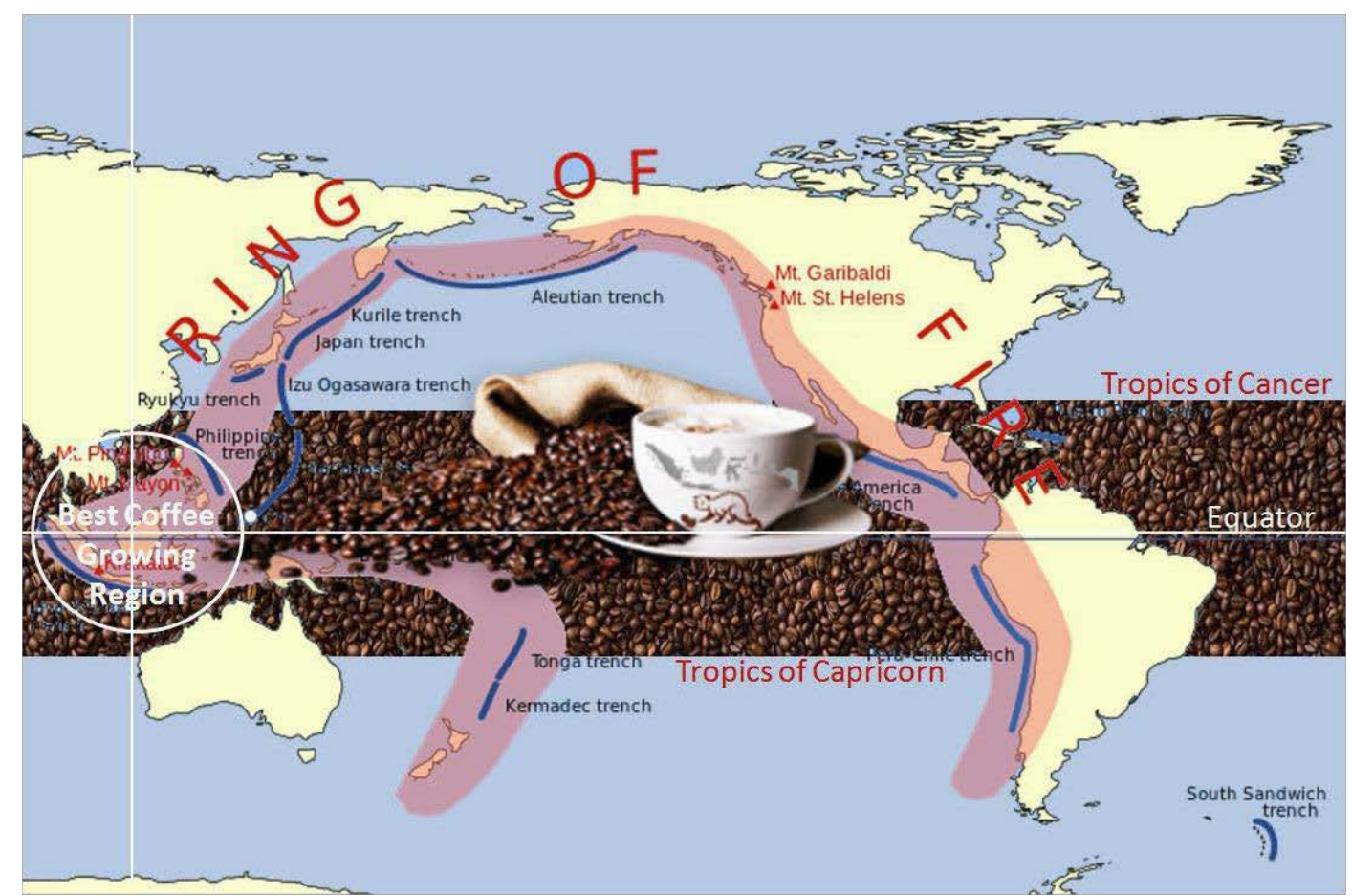

Figure 11 The Ring of Fire and the Bean Belt crossing only in Indonesia 


\section{Cincin Api (The Ring of Fire)}

Di sekitar Ring of Fire (Gambar.11), kepulauan Indonesia sepanjang 3.200 mil (ca $5.150 \mathrm{Km}$ ) dengan 17.000 pulau, 120 gunung berapi aktif, curah hujan yang cukup, tanah yang subur, dan suhu yang ideal telah menyebabkan keberadaan berbagai jenis kopi.

Tanaman kopi lebih menyukai tanah yang subur dan suhu yang ringan, dengan banyak hujan dan matahari yang teduh. Tumbuh terbaik di sebuah sabuk di sekitar bagian tengah dunia, dibatasi oleh Tropics of Capricorn dan Cancer, yang dikenal sebagai Bean Belt. Tanah, iklim dan ketinggian mempengaruhi rasa biji kopi. Indonesia adalah satu-satunya negara di dunia yang disilangkan antara Cincin Api dan Sabuk kopi. Karena itu kopi Indonesia memiliki cita rasa yang sangat unik.

Kopi Arabika khusus adalah produk yang paling populer di Indonesia dan telah mendapatkan pengakuan di seluruh dunia. Ini telah memposisikan Indonesia sebagai eksportir Arabika khusus kedua terbesar di dunia, dengan 150.000 ton ekspor per tahun. Hampir 100 varietas genetik kopi Arabika telah diciptakan sejak 1699 - beberapa di antaranya adalah Sumatra Lintong, Sumatra Kerinci, Sumatra Solok Minang, Jawa Preanger, Jawa Ijen Raung, Perkebunan Jawa, Sulawesi Toraja, Papua Wamena dan banyak lagi.

Kopi Indonesia adalah tentang perjalanan menjelajahi dan menemukan beragam cita rasa kopi yang ditawarkan dikepulauan Indonesia. Oleh karena itu dengan kopi, bambu dan singkong, kita dapat mengkaitkan pariwisata, kuliner dan budaya yang terdiri lebih dari 300 kelompok etnis di Indonesia, yang kebanyakan hidup di daerah pedesaan secara harmonis.

\section{Kopi Indonesia}

Penulis telah mempromosikan kopi Indonesia dengan dukungan dari Konsulat Jenderal Republik Indonesia di New South Wales, Dr. Yayan Ganda Hayat Mulyana dan Pusat Promosi Perdagangan Indonesia (ITPC), yang dipimpin oleh Bapak Agung Haris Setiawan, Direktur ITPC .

Dengan bantuan Asosiasi Kopi Australia dan Indonesia (AICA) yang dipimpin oleh Mr. Toni Marci, seorang Coffee Q Grader yang bersertifikat di bawah Specialty Coffee Association of America, biji kopi yang berasal dari Jawa Barat dimasukkan ke dalam acara Melbourne International Coffee Expo ("MICE"). kompetisi pada Maret 2017. Campuran Filter Kopi Jawa Barat memenangkan Medali Perunggu di “Single Origin Pour Over”. Mudah-mudahan ini adalah awal dari mempromosikan Kopi Indonesia di panggung Internasional. 


\section{Bambu, Tanaman Ajaib}

Bambu memainkan peran sentral dalam upaya mitigasi perubahan iklim Indonesia. Negara ini memperkuat kapasitas komunitas lokal sehingga mereka dapat memperoleh yang terbaik dari sumber daya yang berharga ini.

\section{Bangunan Bambu}

Gambar di bawah ini (Gbr.12) menggambarkan salah satu dari banyak warungwarung kopi yang dapat ditemukan di Java Barat terbuat dari bahan, sambil menikmati kuliner lokal dan biji kopi berkualitas tinggi yang ditemukan di seluruh Indonesia dengan Wi-Fi dan listrik gratis.

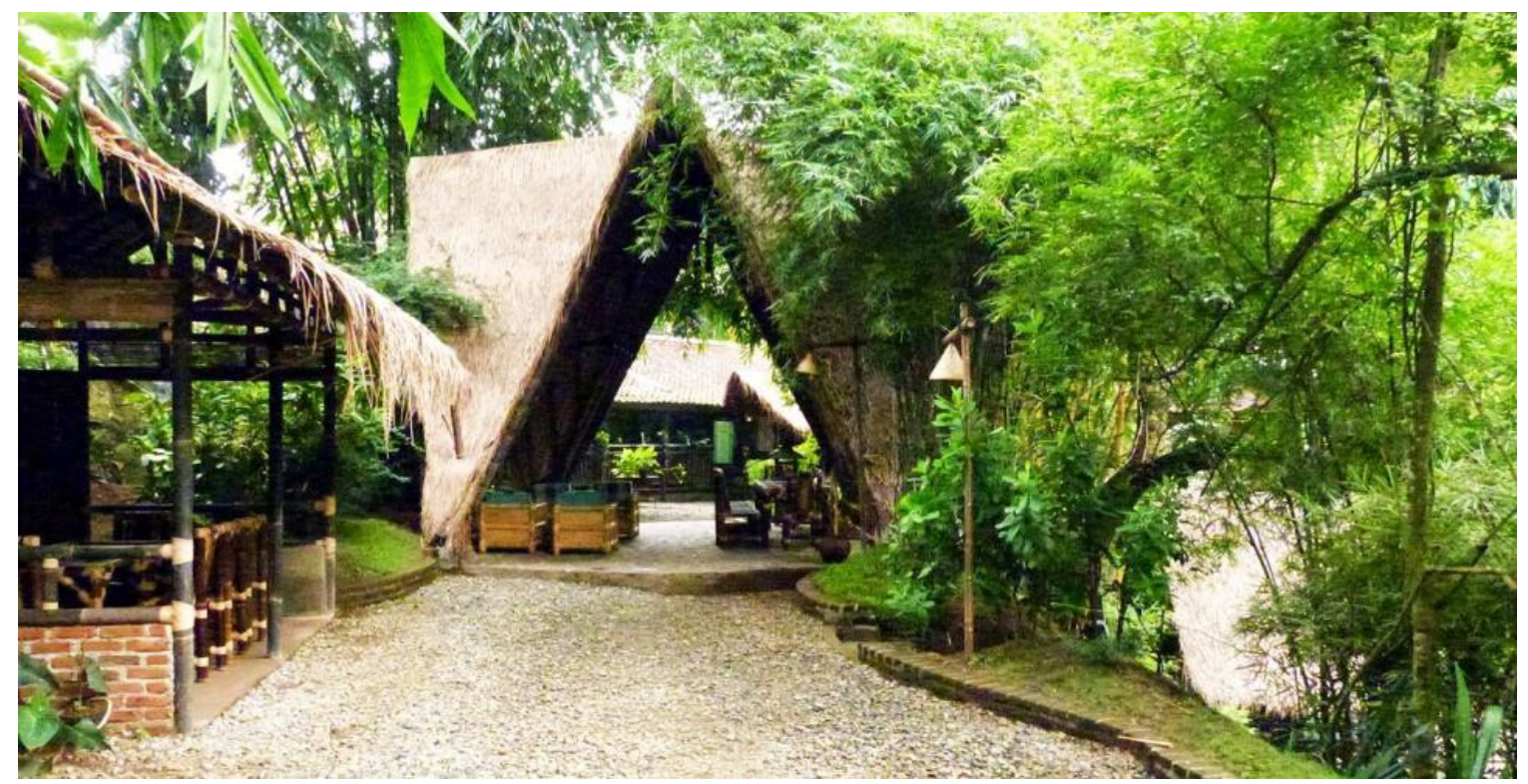

Figure 12 Bamboo Cafe, West Java²

\section{Gassifikasi Bambu (Bamboo Gassification)}

Diagram berikut menggambarkan produksi listrik dalam kolaborasi antara partisipasi masyarakat lokal dalam menumbuhkan dan pemasokan bambu ke produsen listrik lokal, yang dapat ditemukan di Pulau Mentawai, sejak 2015.

\footnotetext{
${ }^{2}$ http://listofhappiness.com/index.php/2016/09/29/makan-tradisional-ala-sunda-di-kebun-awi-kaffee/
} 


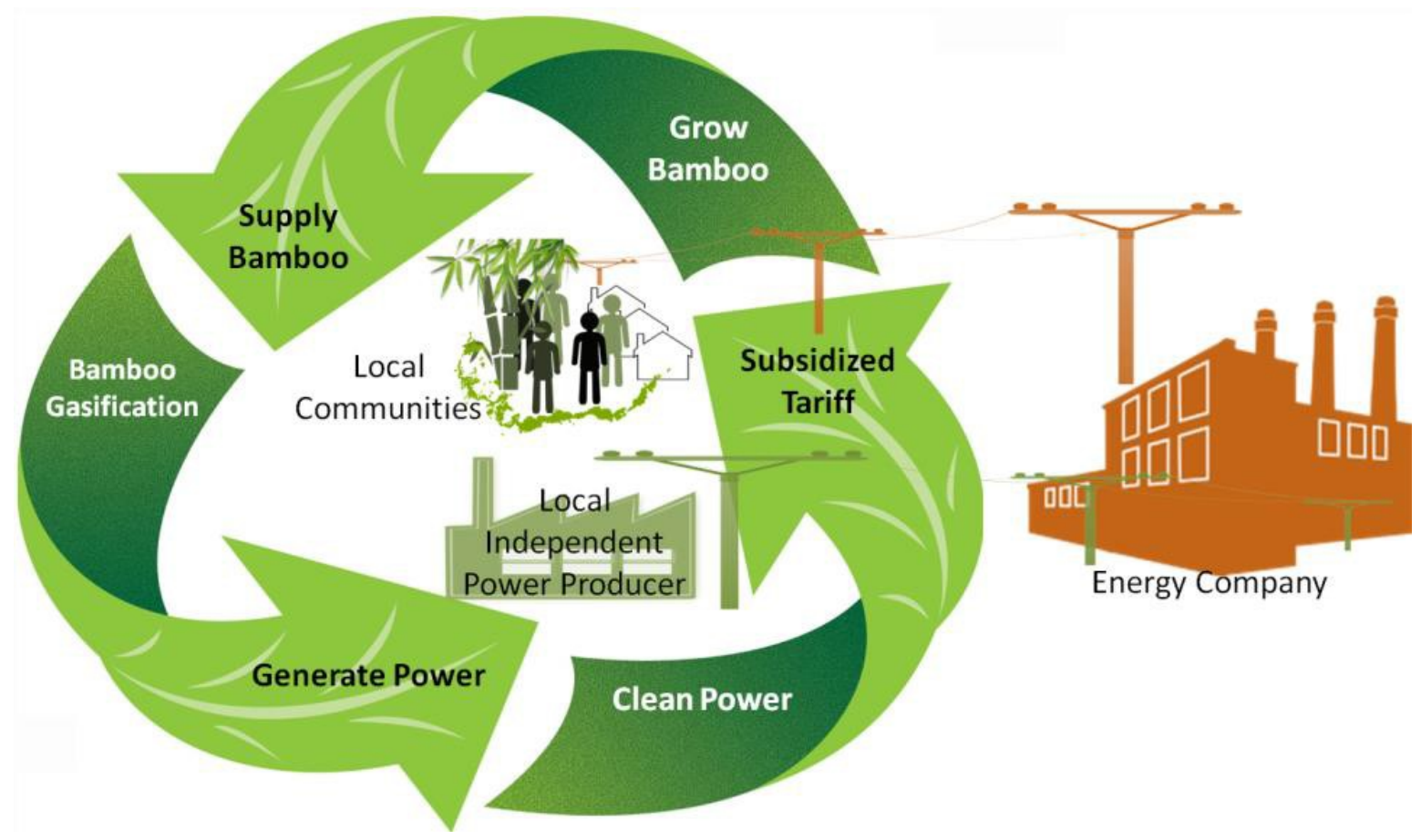

Figure 13 Green Energy Cycle through collaboration

Kepulauan Mentawai adalah rantai sekitar tujuh puluh pulau dan pulau sekitar 150 kilometer di lepas pantai barat Sumatera di Indonesia. Siberut di 4.030 kilometer persegi adalah yang terbesar dari pulau-pulau dan mereka menghasilkan listrik (Gambar. 13) dengan menggunakan "Gotong Royong (kolaborasi)". Ini adalah konsep sosialitas yang akrab bagi sebagian besar masyarakat Indonesia sebagai anggota komunitas yang bekerja sama untuk mencapai tujuan bersama.

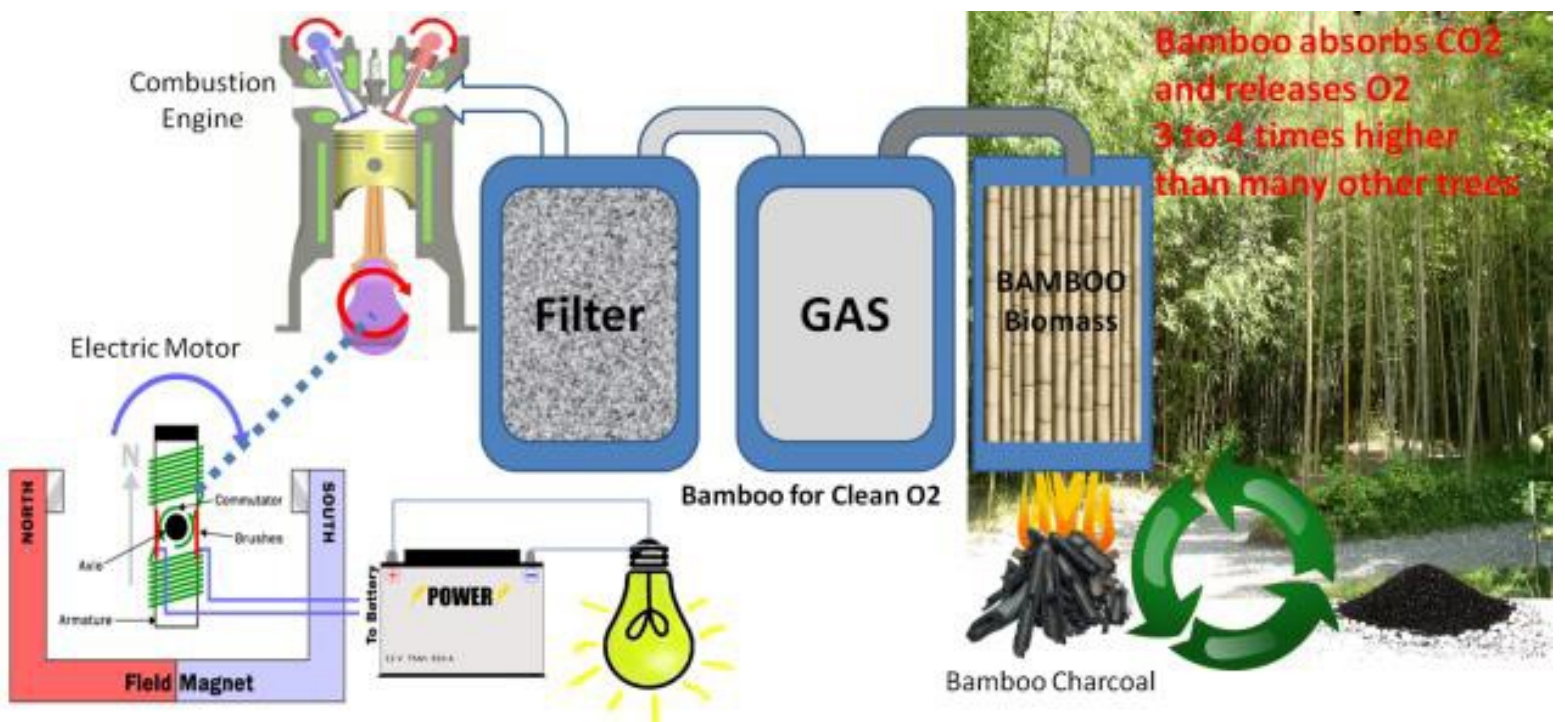

Figure 14 Bamboo Gasification

Produsen listrik independen lokal kemudian mengubah bambu dengan cara gasifikasi 
(Gambar 14) menjadi listrik dan menjualnya ke perusahaan energi, sehingga mereka dapat memasok listrik kepada kontributor masyarakat setempat terkait dengan tarif bersubsidi.

\section{Musik Bambu dengan Angklung}

Selain manfaat bambu yang disebutkan di atas untuk lingkungan, yang terbaik dari semuanya adalah bambu juga dapat dibuat menjadi alat musik. Misalnya Angklung di Indonesia dapat digunakan untuk menyampaikan kedamaian dan harmoni.

Menurut orang Sunda, tabung Angklung melambangkan kehidupan manusia; tabung itu sendiri adalah orang-orang. Angklung tidak bisa menjadi alat seperti itu, jika itu hanya terdiri dari satu tabung. Ini mewujudkan fakta bahwa manusia adalah "hewan sosial," seperti dikatakan oleh Aristoteles, dan bahwa mereka mungkin tidak dapat hidup secara baik dalam isolasi. Tabung besar dan kecil yang terletak di samping satu sama lain di setiap instrumen mewakili pertumbuhan dan kemampuan individu. Ukuran tabung yang berbeda menandakan kebenaran bahwa semua orang memiliki peran berbeda untuk bermain untuk menciptakan semacam kedamaian dan harmoni di dunia ini.

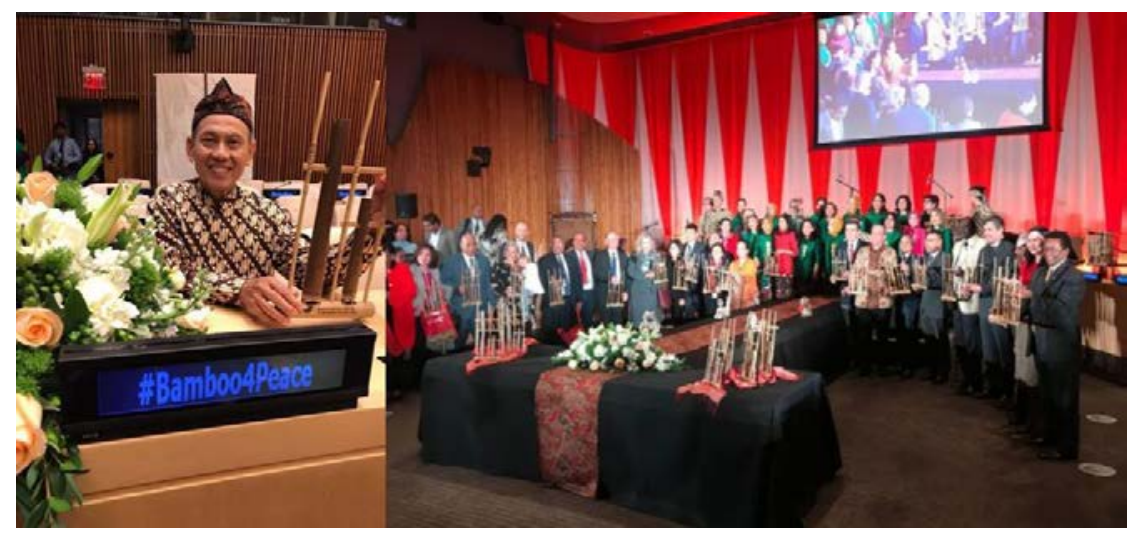

Figure 15 Bamboo for Peace at the UN

Angklung dari Saung Angklung Udjo pertama kali terdengar di gedung PBB di New York pada 30 April 2018 dan ratusan diplomat asing kagum untuk belajar dan berpartisipasi dalam orkestra musik tradisional Indonesia (Gambar 15).

Konser, berjudul "Bambu untuk Perdamaian: Mempesona Suara dan Rhythms Indonesia", diselenggarakan bekerjasama dengan Misi Tetap Republik Indonesia untuk PBB di New York, yang bertujuan untuk meningkatkan intensitas kampanye pencalonan Indonesia untuk Dewan Keamanan PBB keanggotaan tidak permanen untuk istilah tersebut 2019-2020³.

3

https://translate.google.com/translate?hl=en\&sl=id\&tl=en\&u=https://www.antaranews.com/berita/706155/al unan-angklung-gaungkan- perdamaian-di-markas-pbb 


\section{Singkong untuk Plastik Bio-Degradable}

Selain bambu, singkong juga dapat digunakan untuk mendukung pembangunan berkelanjutan dengan memproduksi produk biodegradable yang disebut ecoplas sebagai pengganti plastik berbasis minyak seperti yang digambarkan pada Gambar 16 di bawah ini dari Greenhope.

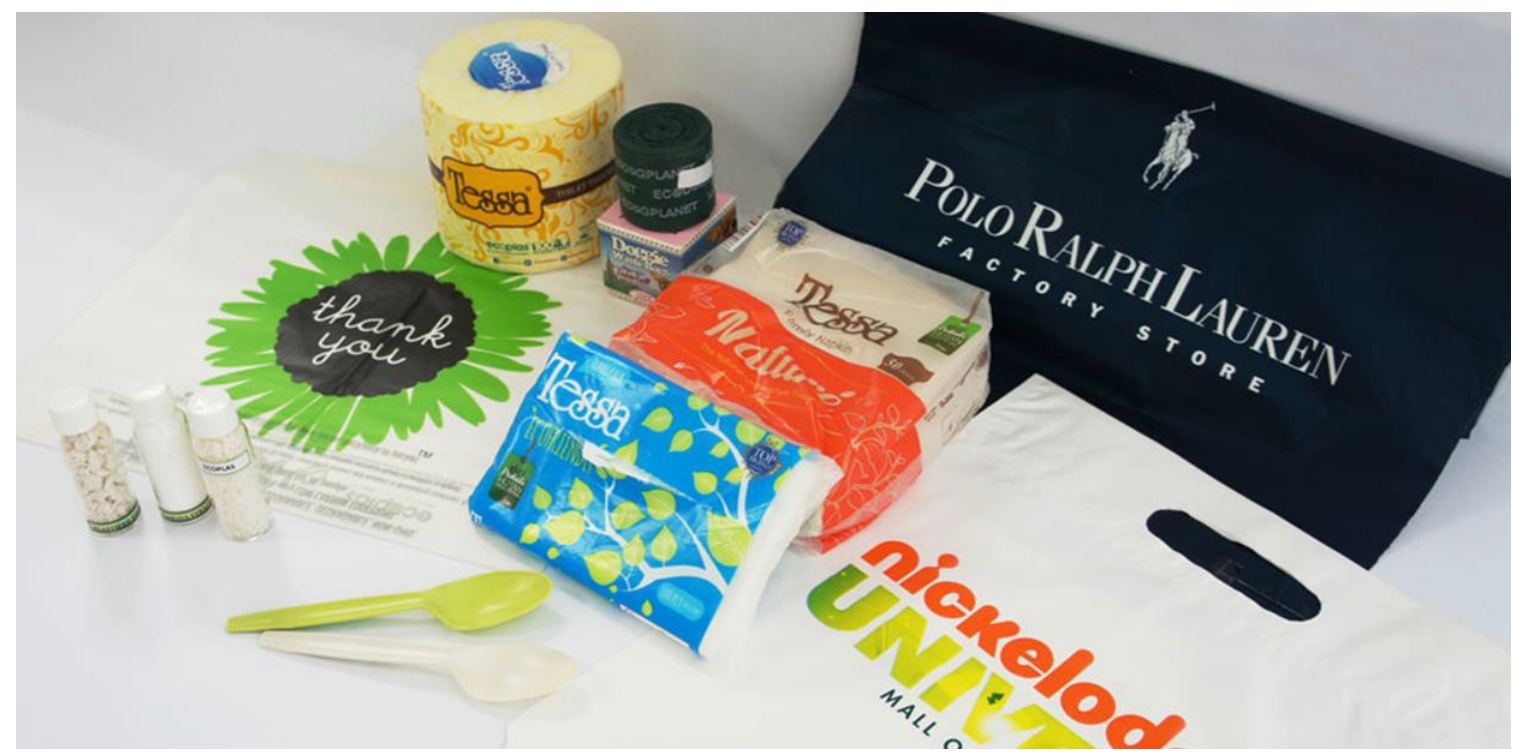

Figure 16 Cassava Based Products

Ecoplas adalah plastik berbasis bio dan terdegradasi yang terbuat dari singkong perdagangan adil (Fair Trading) yang bersertifikat, mendorong dampak positif lingkungan dan sosial. Ecoplas telah menerima banyak pengakuan dan penghargaan secara domestik dan internasional sebagai salah satu bahan berbasis bio yang paling kompetitif terhadap plastik hijau generasi berikutnya / berkelanjutan.

Greenhope adalah perusahaan teknologi hijau dengan memproduksi Ecoplas (plastik berbasis singkong).

\section{HASIL DAN PEMBAHASAN}

Dari hasil pembahasan diatas, ada banyak cara di mana keberlanjutan dapat dicapai melalui perhatian yang lebih besar di daerah pedesaan dan berfokus pada kegiatan inti berkelanjutan yang ada pada saat ini. Contoh-contoh yang disajikan dalam makalah ini termasuk konstruksi bangunan berkelanjutan dan praktik pertanian (termasuk Kopi, Plastik biodegradabel) dan alat musik hanya merupakan beberapa contoh yang menarik yang menyoroti peluang untuk mengembangkan lebih banyak komunitas "Kampung IT” dan ikut membantu mengatasi masalah perubahan iklim 
Selanjutnya untuk kopi, ubi kayu dan biomassa bambu, energi hijau titik air seperti yang ditemukan di kampus Green School di Bali, Indonesia digunakan untuk menghasilkan energi listrik seperti yang digambarkan pada Gambar 17 berikut:

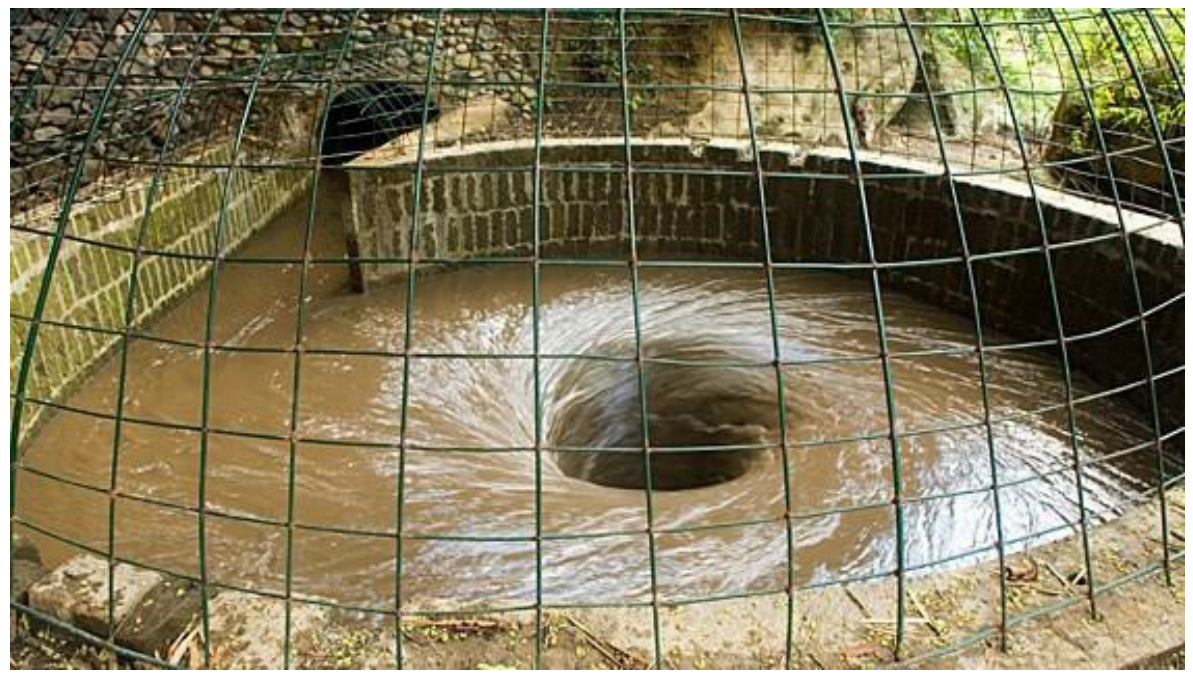

Figure 17 Water Vertex

Green School di Bali ${ }^{4}$ serta Yayasan Bambu Indonesia ${ }^{5}$ dapat digunakan sebagai panduan untuk membangun arsitektur Smartvillage (Kampung IT) di seluruh Indonesia dari Sabang di Sumatra Utara hingga Merauke di Irian Jaya.

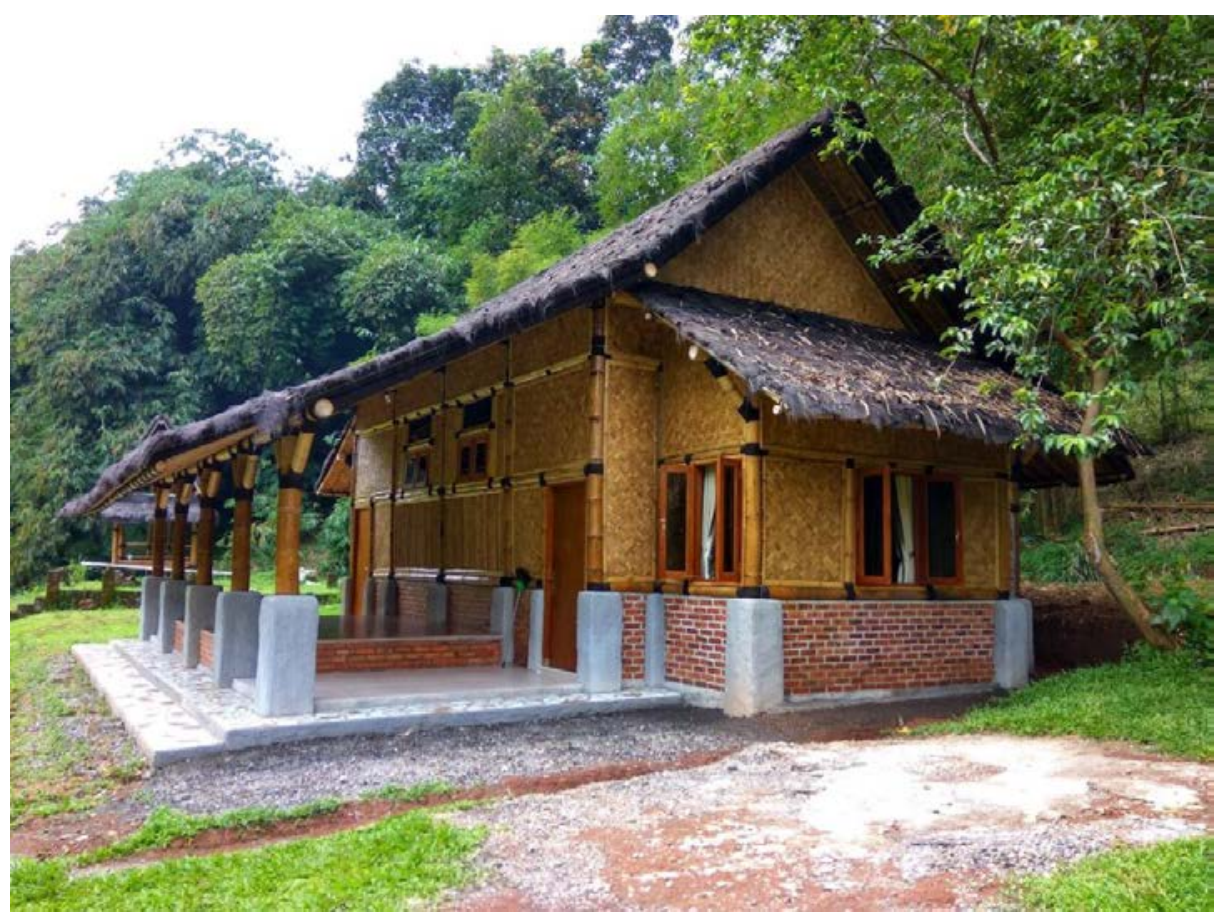

Figure 18 Jatnika's Bamboo House

\footnotetext{
${ }^{4}$ https://www.greenschool.org/

${ }^{5}$ https://www.kemlu.go.id/Majalah/Indoinvites\%20II.pdf
} 
Gambar 18 menggambarkan satu dari ribuan rumah bambu yang dikembangkan dan dibangun oleh Bapak Jatnika Nanggamiharja dari Bamboo Foundation Indonesia, yang telah diekspor ke seluruh dunia.

Untuk memastikan kecukupan pasokan bambu, kami bekerja sama dengan Kementerian Lingkungan Hidup dan Kehutanan Indonesia dan Bambu Nusa Verde, sebuah perusahaan bioteknologi yang mengkhususkan diri dalam budidaya spesies bambu, untuk membudidayakan bambu di Indonesia seperti yang digambarkan pada Gambar. 19 di bawah ini.
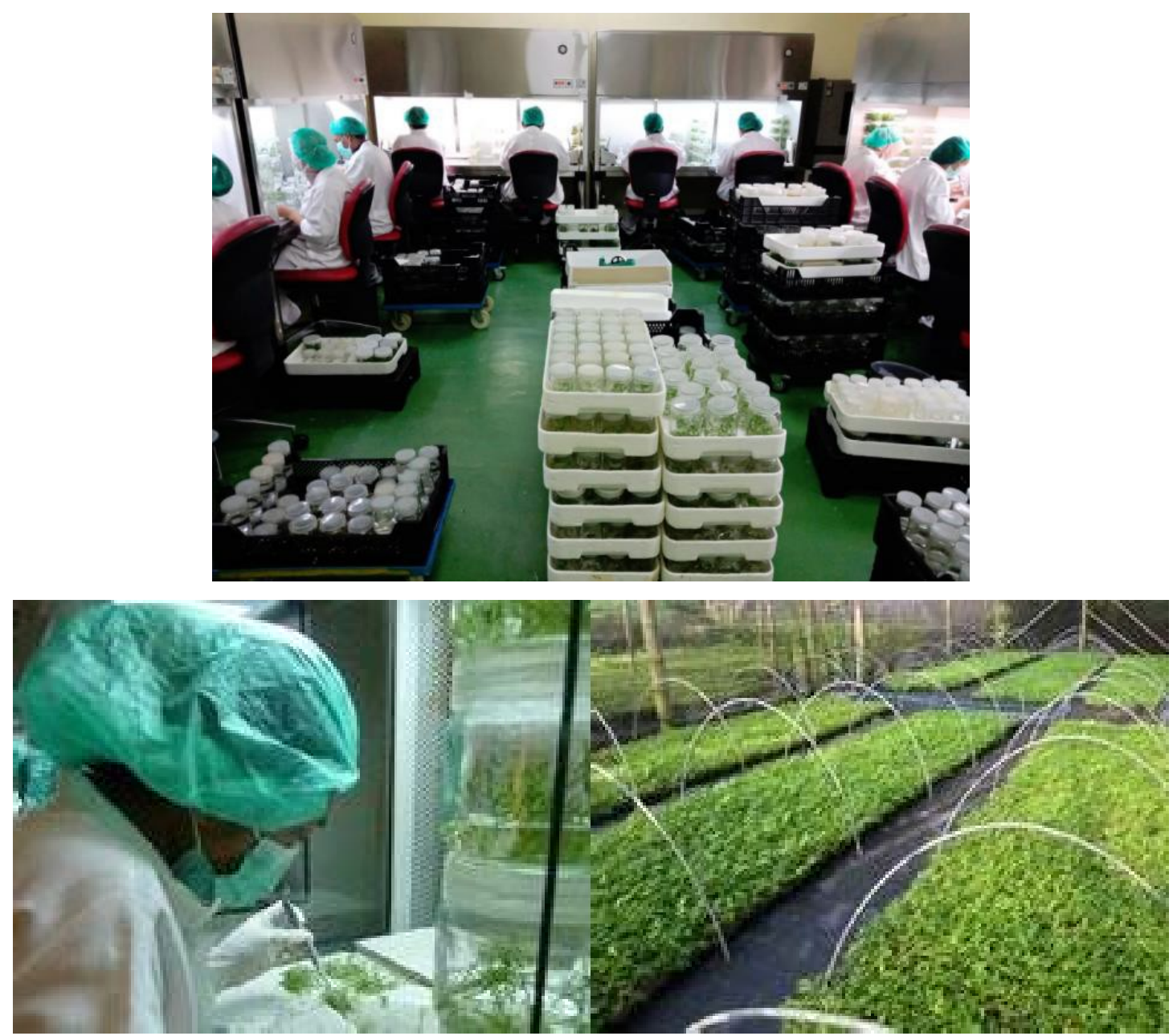

Figure 19 Bamboo Nusa Verde Biotech in Yogyakarta, Central Java

Kantor pusat dan fasilitas produksi berlokasi di Yogyakarta, Indonesia.

\section{SIMPULAN}

Ada banyak cara di mana keberlanjutan yang lebih besar dapat dicapai melalui fokus yang lebih besar di daerah pedesaan dan berfokus pada kegiatan inti berkelanjutan yang ada saat 
ini.

Contoh-contoh yang disajikan dalam makalah ini termasuk konstruksi bangunan berkelanjutan dan praktik pertanian (termasuk Kopi, Plastik biodegradabel) dan alat musik hanya beberapa contoh yang menarik yang menyoroti peluang untuk mengembangkan lebih banyak komunitas “Kampung IT” dan membantu mengatasi masalah perubahan iklim.

\section{UCAPAN TERIMAKASIH}

Bersama ini, saya ingin mengucapkan banyak terima kasih yang sedalam-dalamnya kepada SANYURI, terutama kepada Bapak Komjen. Pol (polri) Binarto, Bapak Arief B. Padmodimulyo, Bapak Kusmutarto Basuki, Ibu S.W Pudji Murtanti, Bapak Prof. DR Agus Muladno B, Bapak Catur Irianto dan teman-teman lainnya di SANYURI yang tidak dapat saya sebutkan satu persatu atas dukungan dan kerja sama yang sangat erat sehingga terbentuk Kampung IT pertama di Indonesia dan secara perlahan-lahan mulai menjangkau desa-desa lainnya tidak saja di Indonesia, tetapi juga di Afrika Selatan, Vietnam dan Australia.

Saya juga sangat berterima kasih kepada Prof Ida Widianingsih dari UNPAD, Prof Janet McIntrye dari Flinders, Australia, Prof Norma Romm dari UNISA (University of South Africa) dan Prof Bambang Laksmono dari UI atas kerja sama dalam riset bersama dengan tema: food, water and energy, sehingga menghasilkan "bottom up approach" dengan pemerdayaan masyarakat di desa-desa berupa Kampung IT yang didukung dengan bambu, kopi dan ketela.

Juga ucapan terima kasih kepada Bapak Yayan Mulyana, Kepala Pusat Pendiikan dan Pelatihan Kementrian Luar Negri RI. Beliau juga sebagai mantan Konjen RI di Sydney (20152017). Atas dukungan Beliau bersama Bapak Arief Santoso (Kadisbun Jabar), Bapak Sammy B. Y. Legi (Pelaku Usaha Kopi Gedongan Coffee House), Bapak Agung Haris Setiawan, mantan Direktur ITPC Sydney atas keberhasilan dalam mempromosikan kopi Indonesia ke Australia, sehingga memenangkan medali perunggu di MICE (Melbourne International Coffee Expo) 2017

\section{Tweet Ahmad Heryawan}

Bronze Medal awards kopi green bean bland, Full wash+red honey score $>80$ pd event MICE Australia 28 maret 2017@humasjabar...

Pak Rudolf, a.n. Gub Jabar n masyarakat Jabar kami terimakasih n appreciate kpd bapak krn telah memfacilitasi kami melalui komoditas kopi mnjadikan nama Jabar n Merah Putih berkibar di MICE 2017 - Pak Arief, Kepala Dinas Perkebunan (Kadisbun) 
Terakhir, ucapan terima kasih juga saya sampaikan kepada Bapak Marc Peteers dari Bambo Nusa Verde di Jogya, Bapak Jatnika Nanggamiharja dari Bamboo Foundation Indonesia dan Bapak Tommy Tjiptadaja dari Greenhope atas dukungannya dalam mempromosikan bambu dan Ecoplas (cassava based plastic) melalui Kampung IT di Indonesia, Afrika Selatan, Vietnam dan Australia.

\section{DAFTAR PUSTAKA}

McIntyre-Mills Janet et al. (2017). Pathways to Wellbeing-Low Carbon Challenge to Live Virtuously and Well: Participatory Design and Education on Mitigation, Adaptation, Governance and Accountability ${ }^{6}$.

McIntyre-Mills Janet et al. (2017). Balancing Individualism and Collectivism7

Wirawan Rudolf (2017), Australian Diaspora in Action. Not Just Empty Promise ${ }^{8}$ (Diaspora Australia Beraksi Bukan Sekedar Berjanji).

\footnotetext{
${ }^{6}$ https://link.springer.com/chapter/10.1007\%2F978-3-319-58014-2_3

${ }^{7}$ https://link.springer.com/book/10.1007/978-3-319-58014-2

${ }^{8}$ http://wirasoftfoundation.org/documents/106406/0/Diaspora+Australia+Beraksi+Bukan+Sekedar+Berjanji+20132017+v2.0.pdf/33a216b3-6a5f-45eb-a289-b27e5c9bab62
} 